\title{
Nursing care for the Amazon population: knowledge production and human resource development
}

\author{
Cuidado de enfermagem à população amazônica: produção de conhecimento e formação de recursos humanos
}

Atención de enfermería a la población amazónica: producción de conocimiento y formación de recursos humanos

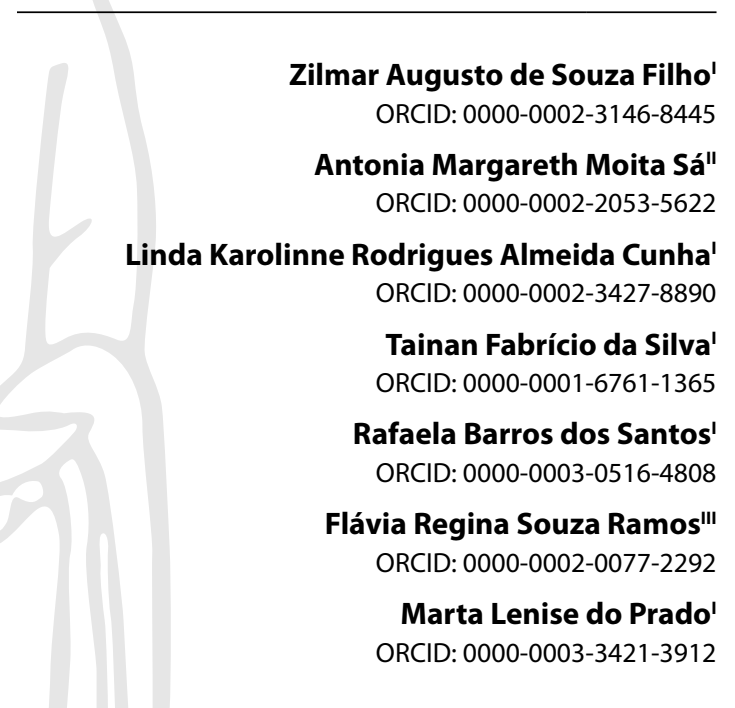

'Universidade Federal do Amazonas. Manaus, Amazonas, Brazil.

"Universidade do Estado do Pará. Belém, Pará, Brazil. I'Universidade Federal de Santa Catarina. Florianópolis, Santa Catarina, Brazil.

How to cite this article: Souza Filho ZA, Sá AMM, Cunha LKRA, Silva TF, Santos RB, Ramos FRS, et al. Nursing care for the Amazon population: knowledge production and human resource development. Rev Bras Enferm. 2022;75(Suppl 2):e20201084. https://doi.org/10.1590/0034-7167-2020-1084

Corresponding author:

Zilmar Augusto de Souza Filho

E-mail: augusto.eem.ufam@hotmail.com

EDITOR IN CHIEF: Dulce Barbosa ASSOCIATE EDITOR: Alexandre Balsanelli

Submission: 11-06-2020

Approval: 06-27-2021

\section{ABSTRACT}

Objectives: to analyze knowledge production adherence from a master's course in nursing in the Amazon to care and health demands in the region, with an emphasis on neglected tropical diseases and traditional populations in the Amazon. Methods: a descriptive study, with a quantitative approach and documentary basis, analyzing dissertations defended in a Graduate Program in Nursing at the Universidade do Estado do Pará in association with the Universidade Federal do Amazonas, from 2012-2019. A descriptive statistical analysis was performed. Results: of the 105 dissertations analyzed, 30 (28.6\%) were related to neglected tropical diseases. Of these, 11 (10.5\%) dealt with Chagas disease, leishmaniasis, tuberculosis, malaria, and leprosy. Traditional populations in the Amazon participated in only $11(10.5 \%)$ studies. Conclusions: knowledge production in a master's course has adherence to care and health demands in the region; however, it needs to enhance its production to strengthen its identity.

Descriptors: Education, Nursing; Education, Higher; Nursing Care; Knowledge; Workforce.

\section{RESUMO}

Objetivos: analisar a aderência da produção de conhecimento de um curso de mestrado em enfermagem na Amazônia às demandas de cuidado e saúde da região, com ênfase nas doenças tropicais negligenciadas e populações tradicionais da Amazônia. Métodos: estudo descritivo, de abordagem quantitativa, de base documental, das dissertações defendidas no Programa de Pós-Graduação em Enfermagem da Universidade do Estado do Pará em associação com a Universidade Federal do Amazonas, no período de 2012-2019. Foi realizada a análise estatística descritiva. Resultados: das 105 dissertações analisadas, 30 (28,6\%) estavam relacionados às Doenças Tropicais Negligenciadas. Destas, 11 (10,5\%) versavam sobre doença de Chagas, leishmaniose, tuberculose, malária e hanseníase. A participação de populações tradicionais da Amazônia foi evidenciada em apenas 11 (10,5\%) estudos. Conclusões: a produção de conhecimento do curso de mestrado analisado possui aderência às demandas de cuidado e saúde da região amazônica, todavia, necessita potencializar sua produção para fortalecer sua identidade.

Descritores: Educação em Enfermagem; Educação Superior; Cuidado de Enfermagem; Conhecimento; Recursos Humanos.

\section{RESUMEN}

Objetivos: analizar la adherencia de la producción de conocimiento de una maestría en enfermería en la Amazonía a las demandas de atención y salud en la región, con énfasis en las enfermedades tropicales desatendidas y las poblaciones tradicionales de la Amazonía. Métodos: estudio descriptivo, con enfoque cuantitativo, con base documental, de las tesis defendidas en el Programa de Posgrado en Enfermería de la Universidade do Estado do Pará en asociación con la Universidade Federal do Amazonas, en el período 2012-2019. Se realizó análisis estadístico descriptivo. Resultados: de las 105 disertaciones analizadas, $30(28,6 \%)$ estaban relacionadas con enfermedades tropicales desatendidas. De estos, $11(10,5 \%)$ se ocuparon de la enfermedad de Chagas, leishmaniasis, tuberculosis, malaria y lepra. La participación de poblaciones tradicionales amazónicas se evidenció en solo 11 (10,5\%) estudios. Conclusiones: la producción de conocimiento del Máster analizado tiene apego a las demandas de atención y salud de la región amazónica, sin embargo, necesita potenciar su producción para fortalecer su identidad.

Descriptores: Educación en Enfermería; Educación Superior; Atención de Enfermería; Conocimiento; Recursos Humanos. 


\section{INTRODUCTION}

The Amazon region has specificities regarding its epidemiological profile if considered in relation to other Brazilian regions. It is one of the largest biomes on the planet in terms of diversity, also in terms of peoples (traditional populations such as indigenous peoples, quilombolas (A quilombola is a resident of a "quilombo" (hinterland settlement founded by people of African origin) and riverside dwellers) and territories (tropical region). The characteristics of life, health and illness scenarios require actions in the field of health that are coherent and supported by knowledge of their peculiarities.

In the Amazon region, inhabit indigenous peoples, artisanal fishermen, riverside dwellers, rubber tappers, quilombolas, nut breakers and collectors of seeds, herbs and vegetable saps, among others. The biome gathers most of the indigenous population in Brazil. The Yanomami Land alone, located in Roraima and Amazonas, has $5 \%$ of the total indigenous population in the country ${ }^{(1)}$. Associated with the particularities of the territory, Amazonian peoples have specific ways of life and are often isolated from health resources. In the epidemiological field, the high incidence of neglected tropical diseases (NTD) coexists with the diseases of civilization, such as psychological distress, cardiovascular diseases, and cancer ${ }^{(2-3)}$.

NTDs are associated with social and economic fragility that affects, above all, people in the tropical region of the world, where the most vulnerable populations in developing countries are concentrated. In a circular dynamic, poverty and limited access to clean water and sanitation contribute to the spread of diseases, while the diseases themselves perpetuate the condition of misery and inequality in endemic areas. More than a health problem, neglected diseases represent an obstacle to the human and economic development of nations ${ }^{(4)}$.

This reality poses a challenge for healthcare as well as for qualified human resource development to face it. These challenges have in common the need for a consistent knowledge base about the healthcare needs and the ways of care provided to the Amazonian population. It is assumed that the creation and consolidation of deep-rooted research and graduate centers dedicated to such demands is strategic and even a justification for strong investment in science and technology in the region.

The master's course in nursing at the Universidade do Estado do Pará (UEPA) and the Universidade Federal do Amazonas (UFAM), academic modality, was the first training offer stricto sensu training in nursing in the region. The lines of research of GPNUR are Public Health Nursing and Disease Epidemiology in the Amazon (RL1) and Education and Healthcare and Nursing in the Amazon (RL2). Since its creation ten years ago, the course has as its area of concentration Nursing in the Context of the Amazon Society, which aims at

[...] conception, development and evaluation of health policies, connected with nursing practices, the theoretical foundations of care and education in health with a view to optimizing quality care for the Amazon population; propose discussions and program actions together with the population and traditional groups of the Amazon, groups at risk and should be directed towards the analysis of everyday phenomena in the Amazonian, urban and rural-riparian society and its relationship with the environment, with a view to quality of care of nursing with the Amazon society ${ }^{(5)}$.

The present study is justified by the commitment to assess the contribution of a master's (MA) course in nursing for knowledge production and qualified resource (HR) development. In this case, the contribution we intend to identify refers to its link with the Amazon population's care needs, emphasizing NTD and traditional populations in the Amazon (TPA). Studies on other diseases of civilization are widely developed in different regions of the country, but a graduate program in the Amazon is strongly committed to studying the region's own diseases.

\section{OBJECTIVES}

To analyze knowledge production adherence from a master's course in nursing in the Amazon to care and health demands in the region, with an emphasis on neglected tropical diseases and traditional populations in the Amazon.

\section{METHODS}

\section{Ethical aspects}

There was no need for approval of this investigation by an institutional Review Board, given its bibliometric character, using publicly accessible sources. It is important to highlight that the information selected for analysis underwent peer review to attest the reliability of results and ensure the scientific rigor required in research of this nature.

\section{Study design, place, and period}

This is a descriptive study with a quantitative approach. The data consisted of a documentary base whose sources were the dissertations defended in the Graduate Program in Nursing (GPNUR) in broad association in the area of concentration nursing in the context of the Amazon society - academic master's degree, from UEPA/UFAM. Data collection occurred between March and May 2010.

It is noteworthy that the Strobe was used to guide the study methodology.

\section{Population and sample; inclusion and exclusion criteria}

All dissertations defended from 2012 to 2019 were analyzed. During the period, 106 dissertations were defended with GPNUR UEPA-UFAM, of which 105 were available in their final version during the data collection period, an inclusion criterion in this study.

\section{Study protocol}

Data were collected directly from the abstracts of dissertations available on the website of GPNUR ( https://www.GPNUR.ufam. edu.br/) . All dissertation abstracts are available by class on the Students UEPA and Students UFAM tabs on the respective website. When the information was not clearly stated in the abstract, the dissertation text was searched in its physical format, available at the program secretariats, at both headquarters - UFAM and UEPA. 
After reading the dissertations' abstracts, the following information was extracted: theme/object and study participants. The information was transferred to an Excel spreadsheet. After the first consolidation, the following highlights were made: themes/ object - those related to NTD as well as those with greater numerical representation; participants - those related to the TPA and other participants with greater numerical representation.

\section{Analysis of results, and statistics}

Descriptive statistical analysis was performed, with records of frequencies (absolute and percentage) of information obtained from the dissertations. Data were compared and correlated in order to understand the phenomenon.

\section{RESULTS}

From 2012 to 2019, 106 dissertations were defended. One was excluded from this research because, at the time of collection, the final version had not been delivered. Thus, 105 dissertations were analyzed. Among these, 30 (28.6\%) had objects related to NTD. The others (75) were related to other objects, such as teaching (8), management (4), aging (10), healthcare in different contexts, complications and populations (25), among others (Figure 1).

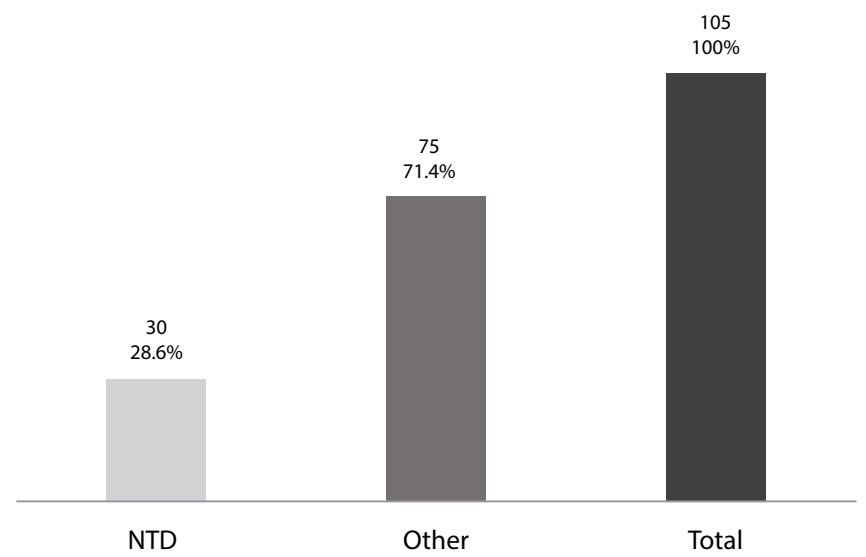

NTD - neglected tropical diseases.

Figure 1 - Dissertations defended in the Associated Graduate Program in Nursing at the Universidade do Estado do Pará and the Universidade Federal do Amazonas, comparison between neglected tropical diseases and other themes

Among the 30 dissertations that had as their theme NTD, Chagas disease, leishmaniasis, tuberculosis, malaria and leprosy were treated in 11 dissertations; the others (19) dealt with other communicable diseases (CD) (Figure 2).

Other conditions of illness/intercurrences in the life process studied that stood out were HIV/Aids, cancer, and chronic disease. This set of themes was addressed in 28 (25.5\%) of the 105 dissertations defended during the study period (Figure 3 ).

Considering the TPA, in only 12 (11.4\%) studies the participation of indigenous people (8), quilombolas (2) and riverside dwellers (2) was found. It is also worth mentioning the performance of $10(9.5 \%)$ studies with older adults, with emphasis on age group, unrelated to traditional populations.

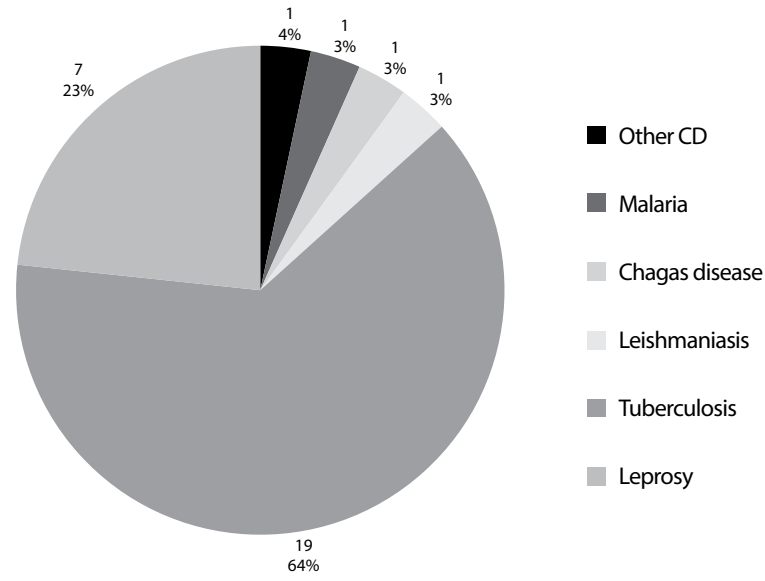

$C D$-communicable diseases.

Figure 2 - Number of dissertations defended in the Associated Graduate Program in Nursing at the Universidade do Estado do Pará and the Universidade Federal do Amazonas, according to the type of neglected tropical disease studied

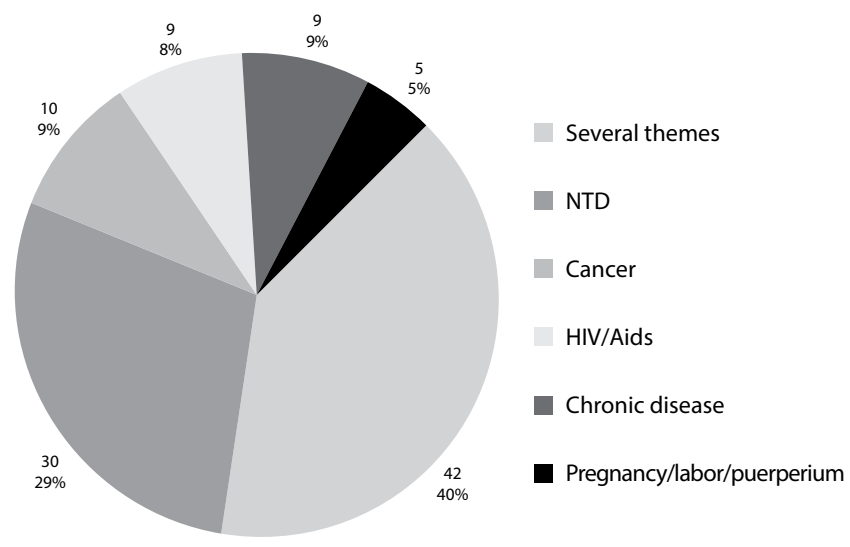

NTD - neglected tropical diseases.

Figure 3 - Number of dissertations defended in the Associated Graduate Program in Nursing at the Universidade do Estado do Pará and the Universidade Federal do Amazonas, according to conditions of illness/intercurrences in the most studied life process

\section{DISCUSSION}

Qualified HR development at the stricto sensu level requires adherence to regional needs. The UEPA-UFAM master's course was created ten years ago with the mission of training masters in nursing capable of producing knowledge and responding to the Amazon region's demands. Such knowledge needs to contribute to overcoming the region's challenges, especially with regard to NTD and TPA. Dissertations defended at the UEPA-UFAM master's course addressed five of the eight NTD: tuberculosis, leprosy, Chagas disease, malaria, and leishmaniasis.

The World Health Organization (WHO) recognizes malaria, dengue, schistosomiasis, tuberculosis, leprosy, leishmaniasis, and Chagas disease as tropical diseases that occur exclusively or especially in the tropics. This designation refers to infectious diseases that proliferate in hot and humid climatic conditions ${ }^{(6)}$, as the case in the Amazon region. These diseases are also considered neglected, as they affect populations that are historically 
vulnerable more strongly and attract few resources from countries and companies with regard to knowledge production, production of medications, vaccines, or therapeutic resources, in addition to deficient planning in the context of public health ${ }^{(7)}$.

Brazil is one of the largest producers of scientific information on the topic NTD. Developed countries do not see themselves fighting tropical health problems; therefore, knowledge production on the subject is low compared to other topics. There is a mismatch between the need to advance knowledge in NTD and the scientific production on them, which indicates the need to intensify investigations in this field ${ }^{(7)}$.

In Brazil, a study that analyzed the knowledge produced about NTD from 2015 to 2018 pointed out 16 areas in the training constitution of the field. Attention is drawn to the insignificant production by nursing, which occupies the penultimate place, following the area of education (which is not within the scope of biologicals and health), which is in tenth position. There is an expected domain of the medical area and health sciences (considering the tradition of Institutes of Tropical Medicine), with a strong presence of public health, which represents the critical basis of the field of health research in Brazil ${ }^{(7)}$.

Nursing represents the largest contingent of workers in health and is spread throughout the national territory, including the Amazon region. Data from the Federal Nursing Council indicate a total of 569,189 nurses registered in Brazil, with $7.41 \%$ or 42,221 in the North region (about $60 \%$ in the states of Amazonas and Pará) (8). If we consider the training data at the graduate level of Brazilian nurses, $10.9 \%$ attended an academic MA's course, 3.6\%, a professional master's course (MP) and 4.7\%, a doctoral (DO) course ${ }^{(9)}$.

Obviously, the distribution of master and doctoral nurses is quite uneven, reflecting the historical concentration of Graduate Programs (GP) in southeastern Brazil. After many years of investment in GP expansion, the Northeast and South regions had a clear impact. Of the current $79 \mathrm{GP}$ in nursing (37 MA/DO, $16 \mathrm{MA}$, $2 \mathrm{DO}, 22 \mathrm{MP}, 2 \mathrm{MP} / \mathrm{DO})$, only four (5\%) are from the North region, followed by 7 (8.8\%) from the Center-West region, 17 (21.5\%) from the South region, 21 (26.5\%) from the Northeast region and 30 (38\%) from the Southeast region. The North region is the most recent in GPNUR. It is believed that it does not reach the training profile (number of masters and doctors) of the Brazilian average, even when considering that training is not only carried out in the region itself $f^{(10)}$.

It is worth considering that programs from other regions do not elect priorities and lines of research aimed at the Amazon context. Although Amazonian nurses undergoing training in other regions may privilege regional themes, a regional program has a differentiated commitment to this investment. Producing knowledge for providing nursing care that adheres to the Amazonian reality is, therefore, a requirement. In this regard, a MA's degree course in nursing located there cannot deviate from this commitment.

However, the epidemiological picture of Latin American countries is challenging, given the coexistence of presumably disparate patterns in the modes of illness, since infectious-parasitic diseases and chronic-degenerative diseases share space, with equivalent degrees of importance, under the point of epidemiological view. There is also the resurgence of diseases such as dengue and cholera, and more recently, yellow fever, Zika and
Chikungunya, the emergence of AIDS and the exacerbation of tuberculosis. In this regard, the emergence of new diseases and the reappearance of old ones, in a complex coexistence due to territorial, economic and social issues, pose new challenges ${ }^{(11)}$.

The small number of studies (only one) on malaria, an endemic disease in the region, is noteworthy. Malaria is a highly transmitted infectious disease in the region, with variable dynamics and spatial distribution, depending on the interaction of environmental, sociocultural, economic and political factors, as well as the healthcare service availability. In Brazil, more than 99\% of malaria cases are registered in the Amazon region, which includes the states of Acre, Amazonas, Amapá, Maranhão, Mato Grosso, Pará, Rondônia, Roraima, and Tocantins ${ }^{(12)}$.

It is necessary to relativize numerical data such as these, when limited to a GP, both because of lack of training opportunities and because the interest in specific topics can lead nurses to seek graduate studies in related areas. As an example, the states of Amazonas and Pará have, respectively, eight and 12 institutions with GP acknowledged by the Coordination for the Improvement of Higher Education Personnel (CAPES - Coordenação de Aperfeiçoamento de Pessoal de Nível Superior) $)^{(10)}$. In these, 12 GPs directly related to health, public health or tropical diseases are offered (according to the GP's name and not including nursing or those from related areas, such as environmental, biological sciences or biodiversity, among others, which can produce knowledge on the themes). There are no systematized data on the number of nurses who graduate in these GP. That is, a considerable contribution to the training of nurses is being made outside the boundaries of the specific area.

Considering only the Graduate Program in Tropical Medicine $(\mathrm{GPMT})^{(13)}$, linked to the Universidade do Estado do Amazonas, there is a total of 35 qualified nurses in the same 10-year period of existence of GPNUR UEPA/UFAM (about a third of the number of graduates). Of these 35 completed works (6 DO and 29 MA), topics related to endemic diseases in the region were covered in about half as follows: malaria (five), tuberculosis (four), dengue/ Chikungunya (four), Chagas disease (three), leishmaniasis (two), in addition to those related to hepatitis, HIV/AIDS, snakebite, STIs, among others.

With this illustration, we want to point out that nurses' research priority themes in the Amazon region in different GP and that, perhaps, they look for a GPNUR precisely because of the possibility of deepening studies of the profession's specific core competencies, directly related to care, management and nursing training. From this, arises the need to analyze the profile of origin, employment relationship and activity interests of graduate students/graduates, not proposing linear readings on the impact and response to regional reality, when multiple training demands are equally important. For example, with greater offers outside of nursing, wouldn't the GP of the area be equally committed to responding to the training of professionals to work in teaching and other specialties in nursing? Even in these cases, how much should they focus on specific issues in the region?

This is evident when looking at other themes that also appeared in the analyzed dissertations. This is the case of studies on cancer and AIDS. Together, these themes represented the majority of those focused on by the studies, demonstrating the 
adherence of GPNUR to the current epidemiological framework, but not specific to the Amazon region. Perhaps, the challenge is a balance that considers the diversity and particularities of the Amazonian territory and peoples, considering their specific ways of life, which demand congruent modes of healthcare. These are issues that lead to future studies.

With regard to TPA, the small number of dissertations that include them as study participants (10.5\%) shows the still fragile scientific production of GPNUR UEPA-UFAM addressed to these populations. The number of studies involving older adults $(9.5 \%)$ is similar to the sum of studies with TPA. This finding does not mean to underestimate the importance of studies with this population, considering the changes in the Brazilian population pyramid. Studies in other fields of nursing work, such as healthcare for women, children, or older adults, for example, are also certainly important in the context of a GPNUR in this context.

Thus, to highlight, in this work, the small number of studies directed to TPA demonstrates that the nursing knowledge produced in this direction still does not feature prominently in its production as a whole. Despite the ethical implications for the implementation of studies with vulnerable populations ${ }^{(14-15)}$, as the case with indigenous populations, this cannot be a barrier to the expansion of studies that ensure not only greater knowledge production, but also to contribute to the improvement of health and nursing care.

Nurses need to be aware of the needs of specific groups, working to reduce the impact of the social determinants of health to which they are subjected, being crucial to know the legislation of the organization of healthcare for populations, the available resources and the duties of professionals in providing care. A study with riverside populations found that most healthcare professionals (community health workers, nurses, doctors, and nursing technicians) are unaware of the legislation that supports the work and assistance to riverine communities, redefines the organization of the Riverside Family Health Teams (RFHT) and Fluvial Family Health Teams (FFHT) of municipalities in the Legal Amazon and on the organization, management and financing of Primary Care services for these populations ${ }^{(16)}$.

Nursing professionals need to incorporate, in the context of health actions, the ability to understand and act according to the Amazon population's cultural specificities, seeking to enable ways to improve access to healthcare services and quality of care and to propose strategies for intervention adequate to sociocultural realities ${ }^{(17)}$.

In the Amazon context, it is necessary to consolidate GPNUR, given the historical regional asymmetry in the offer of courses of this nature. It will be in powerful and consolidated stricto sensu GPNUR, which will promote HR development and disciplinary knowledge production, innovation and multi and interdisciplinary practices for individual and collective care for human health and for management of healthcare services ${ }^{(18)}$. By putting themselves in the context and specificity of each regional university to which they belong, nurses articulate with the situation, national and international contexts, regional demands, economic and social challenges, health indicators and needs social and developmental aspects of the Unified Health System (SUS - Sistema Único de Saúde) ${ }^{(19)}$.

GPNURs are recognized as the most powerful spaces for disciplinary knowledge production. Considering the fact that, in northern Brazil, there are only four stricto sensu courses at the master's level, of which two started in 2019, it can be inferred that the universe of nursing knowledge produced about NTD and/or directed to TPA is very scarce or invisible. This demonstrates a gap in the GPNUR's contribution to strengthening the body of nursing knowledge in this field and, consequently, to the qualification of nursing care in this context.

\section{Study limitations}

Although it cannot be identified as a limitation, since it had as a source of analysis only the knowledge produced in course completion papers, this choice indicates a restriction for potential generalizations. In other words, the analyzes are restricted to a portion of the knowledge produced, not considering published articles or research projects developed by the faculty, which entails further studies.

Likewise, the fact that the region's priority health demands are limited to neglected diseases and traditional populations may represent a limit when considering the region's health demands. In fact, such needs are broader, including maternal mortality, infant mortality, population aging, among others.

\section{Contributions for nursing and health}

This study points to the challenge of expanding nursing knowledge production so that it contributes to the expansion of understanding of the Amazon region's specificities regarding sociocultural and geopolitical issues and the ways of production of life and health of its population. This understanding allows promoting health and nursing actions that favor the overcoming of inequities and difficulties in accessing healthcare services, as well as formulating and implementing public policies with an impact on the quality of life and health of the population in this region.

GPNUR located in the region are those that follows lines of research focused on the Amazon context, dedicating special attention to issues peculiar to the population's health. This study proved to be relevant in its original object and in terms of indicatives applicable to the assessment process itself of the programs, lines and priorities of research in the area.

\section{CONCLUSIONS}

Disciplinary knowledge production and qualified HR development in nursing in the Amazon needs to consider the regional context to promote not only the development of good health practices, as well as translation of knowledge produced, in order to respond to challenges related to care, management and health policies in the region.

NTD are present in several Brazilian regions and in other countries, but, in the case of the Amazon population, they have an important impact on health conditions. Traditional populations are unique to this territory and require approaches that are culturally congruent to their living and health conditions.

The GPNUR located in this region needs to respond to specific demands, developing particular knowledge aimed at this reality, in articulation with other population's healthcare requirements in that territory. 
The present study demonstrated the need to enhance disciplinary production in this field of knowledge and its visibility in the scientific context. Stricto sensu GP constitute powerful spaces for this production. This brings into play the necessary expansion of MA's courses in nursing in the region, as well as the offer of a DO course in nursing, which has not been available so far and would also contribute to overcoming regional asymmetries.

Further studies are recommended that promote the understanding of this scenario, in order to recognize the scientific production of nurses, master's degree and $\mathrm{PhD}$ holders in the region and the contribution of this production to the consolidation of a body of disciplinary knowledge that meets the specificities of nursing care and health to Amazon peoples.

\section{FUNDING}

This study was financed in part by the Coordenação de Aperfeiçoamento de Pessoal de Nível Superior - Brazil (CAPES) - Finance Code 001, and by the Amazonas State Research Support Foundation (FAPEAM - Fundação de Amparo à Pesquisa do Estado do Amazonas) by the Graduate Support Program (POSGRAD) 2020/2021 - Process 062.00702/2020.

\section{REFERENCES}

1. Instituto Sociedade População e Natureza. Amazônia: os povos da floresta [Internet]. Brasília, DF; 2019 [cited 2020 Mar 15]. Available from: https://ispn.org.br/biomas/amazonia/povos-e-comunidades-tradicionais-da-amazonia/

2. Silva ATR. Áreas protegidas, populações tradicionais da Amazônia e novos arranjos conservacionistas. Rev Bras Cienc Soc. 2019;34(99):e349905. https://doi.org/10.1590/349905/2019

3. Léna P. As políticas de desenvolvimento sustentável para a Amazônia: problemas e contradições. Bol Rede Amazonia. 2002;(1):9-22.

4. Instituto Oswaldo Cruz. Conheça as principais doenças tropicais negligenciadas [Internet]. Rio de Janeiro; IOC; 2012[cited 2020 Mar 15]. Available from: http://www.fiocruz.br/ioc/cgi/cgilua.exe/sys/start.htm?infoid=1585\&sid=32

5. Plataforma Sucupira. Coleta Capes: proposta do programa [Internet]. Brasília, DF: CAPES; 2019[cited 2020 Jul 30]. Available from: https:// sucupira.capes.gov.br/sucupira/public/consultas/coleta/propostaPrograma/listaProposta.jsf

6. Camargo EP. Doenças tropicais. Estud Av. 2008;22(64):95-110. https://doi.org/10.1590/S0103-40142008000300007

7. Sobral NV, Miranda ZD, Soares CB, Reis GA. Pesquisadores do domínio das doenças tropicais negligenciadas no Brasil: indicadores científicos do período de 2015 a 2018 . LIS Scholarship Archive. 2019. https://doi.org/10.31229/osf.io/3sedh

8. Conselho Federal de Enfermagem (BR). Enfermagem em números [Internet]. Brasília, DF: Cofen; 2020[cited 2020 Apr 10]. Available from: http://www.cofen.gov.br/enfermagem-em-numeros

9. Machado MH, Wermelinger M, Vieira M, Oliveira E, Lemos W, Aguiar Filho W, et al. Aspectos gerais da formação da enfermagem: o perfil da formação dos enfermeiros, técnicos e auxiliares. Enferm Foco. 2016;6(spc):15-34. https://doi.org/10.21675/2357-707X.2016.v7.nESP.687

10. Plataforma Sucupira. Cursos avaliados e reconhecidos [internet]. Brasília, DF: CAPES; 2020[cited 2020 Jun 13]. Available from: https:// sucupira.capes.gov.br/sucupira/public/consultas/coleta/programa/quantitativos/quantitativoUf.jsf?cdRegiao=1

11. Oliveira RG. Sentidos das doenças negligenciadas na agenda da saúde global: o lugar de populações e territórios. Cienc Saude Colet. 2018;23(7):2291-302. https://doi.org/10.1590/1413-81232018237.09042018

12. Lapouble OMM, Santelli ACFS, Muniz-Junqueira MI. Situação epidemiológica da malária na região amazônica brasileira, 2003 a 2012. Rev Panam Salud Publica [Internet]. 2015[cited 2020 Jun 25];38(4):300-6. Available from: https://www.scielosp.org/article/rpsp/2015. v38n4/300-306/

13. Universidade do Estado do Amazonas, Programa de Pós-Graduação, Medicina Tropical. Apresentação do programa [Internet]. Manaus (AM): UEA; 2020[cited 2020 Jun 25]. Available from: http://www.pos.uea.edu.br/mtrop/

14. Ministério da Saúde (BR). Resolução n 466, de 12 de dezembro de 2012. Aprova as diretrizes e normas regulamentadoras de pesquisas envolvendo seres humanos [Internet]. Brasília, DF: MS; 2012[cited 2020 Jun 20]. Available from: https://bvsms.saude.gov.br/bvs/saudelegis/ cns/2013/res0466_12_12_2012.html

15. Conselho Nacional de Saúde (BR). Resolução no 304, de 9 de agosto de 2000. Aprova normas para pesquisas envolvendo seres humanos: área de povos indígenas [Internet]. Brasília, DF: CNS; 2000[cited 2020 Jun 20]. Available from: https://conselho.saude.gov.br/resolucoes/ reso_00.htm

16. Silva LB, Rodrigues ILA, Nogueira LMV, Silva IFS, Santos FV. Conhecimento de profissionais da atenção primária em saúde sobre política de saúde para populações ribeirinhas. Rev Bras Enferm. 2020;73(5):e20190080. https://doi.org/10.1590/0034-7167-2019-0080

17. Rocha ESC, Toledo NN, Pina RMP, Fausto MCR, D'Viana AL, Lacerda RA. Primary health care attributes in the context of indigenous health. Rev Bras Enferm. 2020;73(5):e20190641. http://doi.org/10.1590/0034-7167-2019-0641

18. Scochi CGS, Munari DB, Gelbcke FL, Erdmann AL, Gutiérrez MGR, Rodrigues RAP. Pós-graduação stricto sensu em Enfermagem no Brasil: avanços e perspectivas. Rev Bras Enferm. 2013;66(spe):80-9. https://doi.org/10.1590/S0034-71672013000700011

19. Parada CGL, Kantorski LP, Nichiata LYI. New paths for the assessment of Brazilian postgraduation and challenges in the Nursing area. Rev Gaucha Enferm. 2020;41(spe):e20190359. https://doi.org/10.1590/1983-1447.2020.20190359 